\title{
GATT adds fuel to patents controversy
}

INDIA remains as suspicious as ever of suggestions that it should follow procedures on the protection of intellectual property, patents and the like, advocated by the industrialized West and, in particular, embodied in the latest version of the General Agreement on Tariffs and Trade (GATT) now being negotiated.

One of the contentious issues is India's patent legislation, which exempts from local protection products (but not processes) judged to be of particular value to the health and education of people in developing countries. But India is particularly disturbed that the new GATT regime (of which it wishes to be a part) will require protection for strains of plants developed abroad in ways that make no sense to Indian farmers.

So farmers and agricultural scientists in India are upset over the government's decision to sign the GATT treaty. They are not convinced by official explanations that signing the treaty will not harm their interests.

The draft treaty proposes the patenting of microorganisms and also stipulates that signatories should provide "for the protection of plant varieties either by patents or by an effective sui generis system or by any combination of these". It is this part that farmers fear will affect their traditional rights to save seeds from one crop to the next.

While farmers in the industrialized West are habitually dependent on private companies for seeds, 80 per cent of seed supply in India is within farmers' control. They reproduce, exchange, breed and sell their seed and plant varieties. Now they fear that they will end up buying seeds from multinational corporations holding the patents and protective certificates on plant varieties and seeds. Agricultural researchers are also concerned that they will be required to pay royalties on protected varieties they may wish to use for genetic enhancement, even by traditional methods.

"We shall have riots on our hands if we ask the farmers not to keep their seeds from one crop to the next", one politician said last week. "Is that what the West really wants?"

The merging of farmers' and scientists' interests has created a strong anti-GATT movement. Cargill Seeds India Limited, a subsidiary of the US company of the same name, was twice physically attacked last year in what was said to be a warning to multinationals to keep out of the seed business in India. With the impending signature of the GATT treaty, the movement last week announced plans for intensifying its agitation. The new protest includes a boycott of seeds produced by multinational companies and the encouragement of seed exchange through farmer-run seed banks throughout India.

But the Indian government says that farmers and scientists are over-reacting. In a statement in parliament last week, commerce minister Pranab Mukherjee said: "There is no obligation on us to patent seeds and we do not intend to do it

but some sort of protection for plant breeders is in our own interests." In the same breath he announced that the government will introduce legislation incorporating "the farmer's right to retain his seed from one crop to another and to exchange seed in traditional manner".

But Vandana Shiva, a United Nations consultant and expert on these issues, says there is no way the government can ensure farmers' rights and researchers' privilege without actually scrapping the offending clause in the treaty. She is angry because Indian negotiators at the Uruguay round did not press for such an amendment.

The sui generis system India intends to adopt is that codified by the 1978 convention of the Union pour le Protection des Obtentions Végétals, or UPOV. This does protect farmers' rights

\section{India pushed about?}

Rights to intellectual property is a contentious topic. Many in India passionately regard the issue as a means of coercion by 'the West' comparable with the diplomatic pressure brought to bear on India by its leadership of the 'non-aligned' group of governments.

But it is a more complicated issue that many will allow. Thus Indian patent law does not allow for the patenting of products, but only of the processes for manufacturing them, while the duration of patent protection (14 years) is less than elswhere.

Moreover, the patenting of naturally occurring materials is not allowed, casting doubt on attempts being made elsewhere to patent human genes or parts thereof.

On seeds, the present practice in India is that the agriculture ministry supports the Indian Institute for Agricultural Research as well as the network of research stations and extension services required to develop improved seeds and to see that they are properly used. No attempt is made to recover from the eventual beneficiaries the costs of research and development, although in principle the government could attempt to do this by adjusting the prices it will pay for crops that are surplus to farmers' own requirements. to save seeds for their own use, but it is restrictuve in the sense that breeders starting with protected varieties cannot commercialize the results of their research. "In simple terms," said a senior agricultural scientist, "it means that India cannot make another green revolution without paying enormous royalties to owners of patented plant varieties.

It seems especially ironical that the proposed regulations should apply to proprietary interests owned by corporations overseas in means of using varieties of plants native to India itself. The controversy is amply illustrated by the case of the neem tree, native to India and traditionally used for a variety of purposes.

The neem has been processed in India for centuries by techniques involving grinding, heating with a variety of solvents, refining, extracting and diluting. Among other things, these processes have been used commercially to yield neem-based pesticides.

But "the West pirated this knowledge of the Indian community," says Vandana Shiva, director of the Foundation for Science, Technology and Natural Resource Policy in Dehra Dun, who complains that broad-based patents held by W. R. Grace, a Florida-based company, mean that Grace now holds the rights to grinding, heating, refining, extracting and diluting parts of the neem to produce pesticides containing azadirachtin.

Under the GATT, the Indian community cannot charge Grace with piracy, says Shiva, because the rights of the community to intellectual property are not recognized. But Grace will have the right to charge India with piracy when Indians, under the "reversal-of-burden-of-proof" clause, would have to prove in court that they have not copied Grace's process. The people of India will be treated as guilty of misusing Grace's patents until they prove themselves innocent.

Whether or not the traditional uses of the neem tree are ever brought to court, Indians are alarmed at the far-reaching implications of certain clauses of the Trade Related Intellectual Property System (TRIPs) proposed by the GATT treaty. They are particularly incensed at the effect of the clause making it incumbent on the defendants in a protection suit to prove their innocence.

In the case of the neem tree, if India were to fail to recognize Grace's patents, the United States would be able in principle to levy tariffs on imports from India until the national economy were sufficiently hurt to force recognition.

K.S.J. 